Article

\title{
Organo-Mineral Fertilization Enhances the Acceptability of Smooth Cayenne Pineapple Fruit (Ananas comosus (L.) Merrill) for European Export and Domestic Consumption in Benin
}

\author{
Elvire Line Sossa ${ }^{1, *}$, Codjo Emile Agbangba ${ }^{2,3}$, Gustave Dagbenonbakin ${ }^{4}$, Roméo Tohoun ${ }^{3}(\mathbb{D}$, \\ Pierre Gbènoukpo Tovihoudji ${ }^{5}$ and Guillaume Lucien Amadji ${ }^{1}$ \\ 1 Laboratory of Soil Sciences, Unit Eco-Pedology, Faculty of Agronomics Sciences, University of \\ Abomey-Calavi, Calavi, 01 P.O. Box 526 Cotonou, Benin; gamadji@yahoo.fr \\ 2 Laboratory of Research in Applied Biology, Departement of Environnement Engeneering, University of \\ Abomey-Calavi, Calavi, 01 P.O. Box 2009 Cotonou, Benin; agbaemile@yahoo.fr \\ 3 Laboratory of Biomathematics and Forest Estimations, University of Abomey-Calavi, \\ Calavi, 03 P.O. Box 2819 Cotonou, Benin; romeotohoun@gmail.com \\ 4 National Institute of Agricultural Research of Benin, 01 P.O. Box 884 Abomey-Calavi, Benin; \\ dagust63@yahoo.fr \\ 5 Laboratory of Hydraulics and Environmental Modeling (HydroModE-Lab), University of Parakou, \\ 03 P.O. Box 351 Parakou, Benin; pierretovihoudji@yahoo.fr \\ * Correspondence: elvas2@yahoo.fr; Tel.: +22-995-858-391
}

Received: 15 December 2018; Accepted: 30 January 2019; Published: 25 March 2019

\begin{abstract}
Heterogeneity in pineapple fruit quality explains the low export volume of fruits from Benin to the international market. This work aims to investigate influences of organo-mineral fertilizer on a) pineapple fruit yield, b) fruit quality and the proportion of fruits meeting European export standards, and c) fresh fruit acceptability for domestic consumption. The experimental design is a split-plot with three replications where the main factor is organic manure (poultry litter) (P0 $=0 \mathrm{tha}^{-1}, \mathrm{P} 1=5 \mathrm{t} \mathrm{ha}^{-1}, \mathrm{P} 2=10 \mathrm{tha}^{-1}$ ) and the sub-plot factor, N-P-K fertilization in $\mathrm{kg} \mathrm{ha}^{-1}$ (T0:100-30-150, T1: 200-60-300, T2: 400-120-600, and T3: 600-180-900). To evaluate the percentage of fruit meeting European standards, a generalized linear model with binomial error structures was used. A sensorial test was carried out on fresh pulp to assess the preference of fruit meeting domestic criterion. A preference mapping was assessed through an acceptability test with a nine-point hedonic scale. Organo-mineral fertilizer significantly improved fruit weight $(p=0.012)$, fresh juice weight $(p=0.042)$, total soluble solids $(p=0.032)$, and the percentage of fruits meeting European standards $(p<0.001)$. Better fruits meeting export standards were found with treatments P1T1, P2T0, and P2T3 $(83.33 \pm 28.87 \%)$. Fruits from treatments P0T2, P2T1, P1T3, and P2T2 were highly accepted for domestic consumption (70\%). The results suggested that organo-fertilizer producing fruit achieving exportation standards may differ from those satisfying domestic preferences. Moreover, the findings suggested that the ratio crown length: fruit length, which is a key ratio for exportation standards, is not related to physico-chemical quality. Finally, the findings have implications for the sustainability of pineapple production for domestic and exportation purposes.
\end{abstract}

Keywords: integrated fertilization; quality; consumers; standards

\section{Introduction}

Pineapple is the second most popular tropical fruit in world trade and contributes to more than $20 \%$ of all production. The rate of production also continues to increase, with a $90 \%$ increase 
between 1998 (13.1 million tons) to 2013 (24.8 million tons) [1]. The most cultivated pineapple variety in Benin is "smooth cayenne" with an average production of $32,800 \mathrm{~kg} \mathrm{ha}^{-1}$ [2] and a rate of $80 \%$ of exported volumes [3]. In Benin, production has grown largely due to increasing demand from regional markets, especially Nigeria. Farmers' access to international markets is limited by quality and standards requirements covering agricultural practices such as traceability, pesticide residues, hygiene, etc. [4]. Beyond their visual appearance, consumers expect quality in terms of their organoleptic, sanitary, and nutritional aspects [5]. Pineapple cropping, in most countries, is dominated by conventional monocropping with high levels of agrochemical inputs [6] due to nitrogen $(\mathrm{N})$ and potassium $(\mathrm{K})$ fertilization $[7,8]$, weed management, crop protection, and flowering induction. This intensive monocropping is known to increase tropical soil depletion, pollution, and erosion [9-11]. In Benin, [12] found that pineapple monocropping causes soil and biodiversity degradation. It is well known that mineral fertilization, in the absence of organic amendment supply, causes soil acidification in the short and long term [13-15]. Most existing studies in controlled experiments as well as on-farm demonstrations reported substantial positive effects of the combined application of organic amendments and mineral fertilizers in addressing soil fertility depletion by preventing soil acidification and improving the water and nutrient holding capacity of the soil, thereby minimizing leaching losses, which to lead to increased crop yields [16,17]. The integrated management of fertilization must attempt to ensure both enhanced crop productivity and safeguarded environment. Literature regarding the effects of organic or organo-mineral fertilizer on pineapple are little documented. [18] found that the quality of fruit for the pineapple 'Queen Victoria' was significantly improved with integrated fertilization, with fruit weight similar to that of conventional fertilization. [19] only described the livestock component of the smallholder farms of Uganda with the aim of proposing a better integrated pineapple crop-livestock. Chemical fertilization represents a large part of total production costs [18]. Pineapple requires a large amount of potassium $\left(10-20 \mathrm{~g} \mathrm{plant}^{-1}\right)$ and nitrogen $\left(4-14 \mathrm{~g} \mathrm{plant}^{-1}\right)[7,20]$. Conversely, studies are lacking on alternative pineapple cultivation practices that could replace $\mathrm{N}$ and $\mathrm{K}$ chemical fertilizers. In China, the addition of peanut-press pulp liquid to the usual chemical fertilizer had interesting effects on fruit weight and organoleptic quality [14]. In this study, we hypothesize that organo-mineral fertilization would improve fruit quality and, as a result, determine fruit acceptability for exportation or for local consumption.

The objectives were therefore to investigate the influences of organo-mineral (poultry litter associated with NPK) fertilizer a) on pineapple fruit yield, b) on fruit quality and proportion of fruits meeting European export standards, and c) on the acceptability for domestic consumption. The results of this work will help to improve production since consumer expectations are increasingly oriented towards high quality agri-food products, especially for fruits and vegetables [18].

\section{Materials and Methods}

\subsection{Experimental Site}

The trial was carried out in the Atlantic department in the south of Benin $\left(1^{\circ} 59^{\prime} \mathrm{N}\right.$ and $\left.2^{\circ} 15^{\prime} \mathrm{E}\right)$. The soil is of acrisoil type and average annual rainfall is $1200 \mathrm{~mm}$. Soil texture is sandy loam. The sand and silt rates were $82.5 \%$ and $5 \%$ respectively. The nitrogen content is 0.09 with a weak acid $\mathrm{pH}(6.5)$. The carbon/nitrogen ratio is 11.2. The organic matter content of $1.4 \%$ is low. Soil potassium content is low $\left(0.04 \mathrm{Cmol} \mathrm{kg}^{-1}\right)$. The content of available phosphorus in soils by Bray 1 is also low $\left(6 \mathrm{mg} \mathrm{kg}^{-1}\right)$. The soils are poor in exchangeable $\mathrm{Ca}$ and $\mathrm{Mg}\left(1.8\right.$ to $\left.2.9 \mathrm{Cmol} \mathrm{kg}^{-1}\right)$. The sum of bases and cation exchange capacity are low (4.9 to $\left.5.6 \mathrm{Cmol} \mathrm{kg}^{-1}\right)$.

\subsection{Experimental Design and Treatments}

The trial was carried out in the Atlantic department in the south of Benin between 23 December 2013 and 30 May 2015. The experimental design was a split-plot with 3 replications where the main factor is organic manure (poultry litter) at 3 levels in $\mathrm{tha}^{-1}$ (P0: 0, P1: 5, P2: 10) and the sub-plot factor, 
N-P-K fertilization with 4 modalities in kg ha ${ }^{-1}$ (T0: 100-30-150, T1: 200-60-300, T2: 400-120-600 and T3: 600-180-900). Each experimental unit consisted of 6 lines of 5 plants. The line spacing was $0.8 \mathrm{~m}$ and $0.4 \mathrm{~m}$ between planting holes making a density of 60,000 plant ha $^{-1}$. Planting material of smooth cayenne variety, weighing between 450 and $600 \mathrm{~g}$ plant $^{-1}$ were used. A uniform size of material was used in each replication.

The poultry litter used contained $1.8 \%$ of nitrogen, $1.9 \%$ of phosphorus, $1.7 \%$ of potassium, $6.7 \%$ of calcium, and $1.0 \%$ of magnesium. The organic matter content was $68.1 \%$. The carbon/nitrogen ratio was $19.4 \%$.

The mineral fertilizers used were: urea $(46 \% \mathrm{~N})$, triple superphosphate $\left(46 \% \mathrm{P}_{2} \mathrm{O}_{5}\right)$, and potassium sulfate $\left(\mathrm{K}_{2} \mathrm{SO}_{4}, 50 \% \mathrm{~K}_{2} \mathrm{O}, 45 \% \mathrm{SO}_{3}\right)$. The first fertilizer application was done a week after planting (P2O5), the second 45 days after planting (DAP) $\left(1 / 5 \mathrm{~N}+1 / 6 \mathrm{~K}_{2} \mathrm{O}\right)$, the 3 rd $90 \mathrm{DAP}\left(1 / 5 \mathrm{~N}+1 / 6 \mathrm{~K}_{2} \mathrm{O}\right)$, the 4 th at $135 \mathrm{DAP}\left(1 / 5 \mathrm{~N}+1 / 6 \mathrm{~K}_{2} \mathrm{O}\right)$, the 5 th DAP $180\left(1 / 5 \mathrm{~N}+1 / 6 \mathrm{~K}_{2} \mathrm{O}\right)$, and the 6 th at $225 \mathrm{DAP}$ $(1 / 6 \mathrm{~K} 2 \mathrm{O})$. Flowering induction was carried out ten months after planting by means of carbide of calcium $\left(\mathrm{CaC}_{2}\right)$, a compound producing acetylene when it reacts with water. A kilogram of product was diluted in a barrel of 200 liters. Each plant received $50 \mathrm{~cm}^{3}$ of acetylene carbide between $6 \mathrm{am}$ and $8 \mathrm{am}$.

\subsection{Fruit Morphological and Physico-Chemical Characteristics}

Twelve fruits per experimental unit were harvested at maturity C4 (fully colored fruit). Fruit, crown and infructescence weight were taken using a brand (DH2-000050, \pm 0.0001 balance, Zawiera, Tianjin, China). Fruit core diameter and crown length were measured using a tape. Each fruit was peeled and crushed. The pulp was pressed and filtered to extract fresh juice and the juice yield was measured. Brix (total sugars) juice was determined using a digital refractometer (HI96801, Hanna Instruments, Bucharest, Romania) and $\mathrm{pH}$ was determined using a $\mathrm{pH}$ meter $(\mathrm{HI} 96107, \pm 0.1 \mathrm{pH}$, Hanna Instruments, Villafranca Padovana, Italy).

To compute the percentage of exportable pineapple fruits per treatment, minimum quality criteria for fruits to meet European export standards include: the fruit weight should be between 0.70 and $2.75 \mathrm{~kg}$, the ratio crown: infructescence length should be between 0.5 and 1.5 , and total soluble solids (TSS) should be at least 12 Brix [21,22].

\subsection{Sensorial Tests}

The selection of tasters was made according to [23] and [24]. Fifty panelists were selected and trained for the tasting test. Two sections of tests were carried out on different days. The sensory characteristics assessed were the sweetness, acid taste, aroma and fiber of fresh fruit pulp, with an intensity rating test using a scale of 5 categories at levels ranging from "No (acid, sweet, aroma, fiber)" to "extremely (acid, sweet, aroma, fiber)". An overall acceptability test was done with a nine-point hedonic scale.

\subsection{Statistical Analysis}

The software R 3.5.0 [25] was used for all statistical analyses. A linear mixed model was used for studying the effects of organic manure (poultry litter) and mineral fertilizer on yield and its components. Means were separated with a least significant difference (LSD) test [26] using the Imer function of a ImerTest package [27]. For the percentage of fruit meeting European standards, the generalized linear mixed model with bêta error structures was used.

A $t$-test was used to compare the mean value of the sensorial parameter for a given treatment to the overall mean for all treatments $[25,28]$. The most characteristic variables of a treatment are those whose associated $\mathrm{t}$-value are greater in absolute value than 2 . Moreover, if this value test is positive for a treatment, the sensorial variable has a high value for the treatment under consideration. In contrast, if the value is negative, the treatment has a low value for the parameter. To evaluate the acceptability of pineapple for domestic consumption, a principal components analysis was done on sensorial data. 
Then, a preference mapping was assessed on the coordinates of the treatments on the first two principal components and acceptability test score with a nine-point hedonic scale. A quadratic relationship was assumed between acceptability and sensory variables. The packages FactoMine $\mathrm{R}$ and SensoMine $\mathrm{R}$ were used for these purposes.

\section{Results}

\subsection{Influence of Organo-Mineral Fertilization on Pineapple Yield Parameters}

The analyses of trials revealed that organic and/or chemical fertilizer had significant effect on fruit weight attributes (Table 1, Figure 1A-D). The organic manure associated with mineral fertilizer had a significant effect on the fruit weight and the ratio crown length: fruit length. The highest fruit weight was obtained with treatments P1T3 $(2.33 \pm 0.10)$ (Figure 1A). Only the effect of mineral fertilizer was significant on crown length and weight (Figure 1B-C). Treatment T1 had given taller and heavier weight crown. The lower ratio crown length: fruit length was observed with P1T3 $(0.43 \pm 0.02)$, whereas the higher with P0T1 (0.59 \pm 0.03$)$ (Figure 1D).

Table 1. Influence of organic and mineral fertilizer on yield parameters.

\begin{tabular}{cccccccccc}
\hline & & \multicolumn{2}{c}{ Fruit Weight } & \multicolumn{2}{c}{ Crown Length } & Crown Weight & \multicolumn{2}{c}{$\begin{array}{c}\text { Ratio Crown Length: } \\
\text { Fruit Length }\end{array}$} \\
\cline { 2 - 10 } Factors & df & F & Prob & F & Prob & F & Prob & F & Prob \\
\hline Organic & 2 & 0.11 & 0.068 & 0.20 & 0.817 & 0.90 & 0.420 & 0.54 & 0.591 \\
Mineral & 3 & 0.42 & 0.036 & 3.23 & 0.042 & 3.02 & 0.041 & 2.81 & 0.063 \\
$\begin{array}{c}\text { Organic:Mineral } \\
\text { ICCBlock }\end{array}$ & 6 & 0.67 & 0.012 & 2.28 & 0.074 & 1.95 & 0.117 & 2.70 & 0.041 \\
\hline \multicolumn{3}{c}{28.68} & F = F value; Prob = probability; ICCBlock = intra-class correlation of blocks.
\end{tabular}

\subsection{Effects of Organo-Mineral Fertilization on Fruit Quality and Proportion Meeting European Standards}

Significant effect of the interaction of organic fertilizer and mineral fertilizer was observed on fresh juice weight, $\mathrm{pH}$, total soluble solids, and on the percentage of fruits meeting European standards (Table 2). The highest fresh juice volume $(1.15 \pm 0.04 \mathrm{~L} /$ fruit) was observed with P1T3 while the lowest with P0T1 (0.74 $\pm 0.05 \mathrm{~L} /$ fruit) (Figure 2A). The highest $\mathrm{pH}$ (Figure 2B) was obtained with P0T2 (5.87 $\pm 2.13)$ and P2T2 $(5.84 \pm 2.06)$ while the more acidic fruit was observed with P1T2 $(5.58 \pm 0.60)$ and P1T0 (5.55 \pm 0.58$)$. The treatments P2T2 and P2T3 yielded the highest total soluble solids $(17.71 \pm 3.94$ and $17.21 \pm 3.95$ respectively) (Figure 2C). The generalized linear beta model suggested significant effects of organic and mineral fertilizer on percentage of fruits meeting export standards (Figure 3). A higher percentage $(83.33 \pm 28.87 \%)$ was found with treatments P1T1, P2T0, and P2T3.

Table 2. Influence of organic and mineral fertilizer on fruit quality attributes.

\begin{tabular}{|c|c|c|c|c|c|c|c|c|c|}
\hline \multirow[t]{2}{*}{ Factors } & \multicolumn{3}{|c|}{$\begin{array}{l}\text { Fresh Juice } \\
\text { Weight }\end{array}$} & \multicolumn{2}{|c|}{ Fresh Juice pH } & \multicolumn{2}{|c|}{$\begin{array}{l}\text { Total Soluble } \\
\text { Solids }\end{array}$} & \multicolumn{2}{|c|}{$\begin{array}{c}\text { Percentage of Fruits Meeting } \\
\text { European Standards }\end{array}$} \\
\hline & df & $\mathbf{F}$ & Prob & $\mathbf{F}$ & Prob & $\mathbf{F}$ & Prob & $\mathbf{F}$ & Prob \\
\hline Organic & 2 & 0.18 & 0.831 & 7.03 & $<0.001$ & 12.26 & $<0.001$ & 20.42 & $<0.001$ \\
\hline Mineral & 3 & 0.59 & 0.019 & 5.78 & $<0.001$ & 13.76 & $<0.001$ & 5.17 & 0.007 \\
\hline Organic:Mineral & 6 & 1.34 & 0.042 & 3.72 & 0.002 & 2.39 & 0.032 & 6.07 & $<0.001$ \\
\hline ICCBlock & & 21.13 & & 58.14 & & 0.00 & & & \\
\hline
\end{tabular}



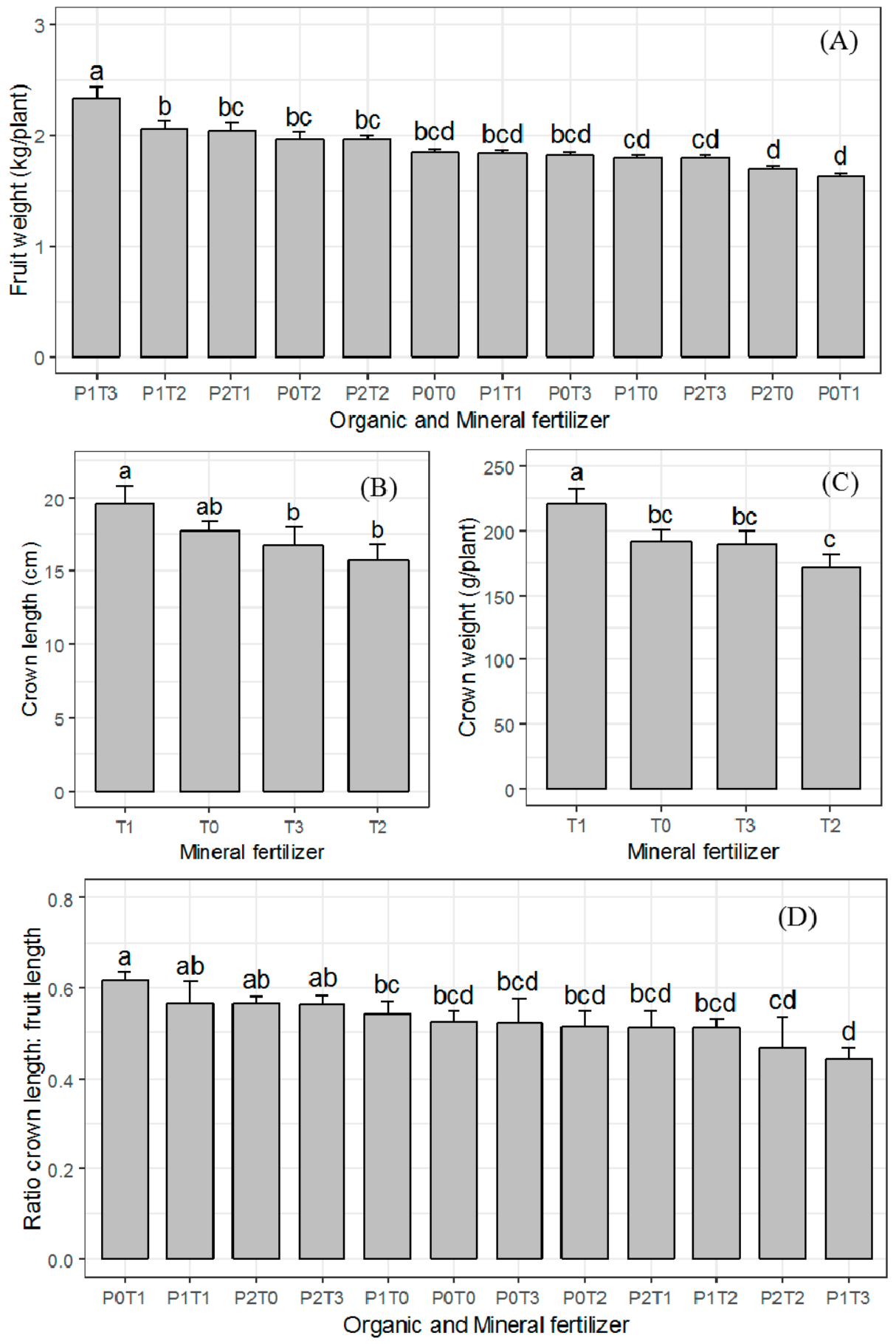

Figure 1. Effect of organo-mineral fertilizer on average: (A) fruit weight; (B) crown length; (C) crown weight, and (D) ratio crown length: fruit length. T0: $=100$ N-30 P-150 K, T1: 200 N-60 P-300 K, T2: 400-120-600, and T3: 600-180-900 ( $\left.\mathrm{kg} \mathrm{ha}^{-1}\right)$, P0T0: $0 \mathrm{t} \mathrm{ha}^{-1}$ of poultry litter and N-P-K in $\mathrm{Kg} \mathrm{ha}^{-1}$ 100-30-150, P0T1: $0 \mathrm{t} \mathrm{ha}^{-1}$ of poultry litter and N-P-K in $\mathrm{Kg} \mathrm{ha}^{-1}$ 200-60-300, P0T2: $0 \mathrm{t} \mathrm{ha}^{-1}$ of poultry litter and N-P-K in Kg ha ${ }^{-1} 400-120-600$, P0T3: $0 \mathrm{t} \mathrm{ha}^{-1}$ of poultry litter and N-P-K in $\mathrm{Kg} \mathrm{ha}^{-1}$ 600-180-900, P1T0: $5 \mathrm{t} \mathrm{ha}^{-1}$ of poultry litter and N-P-K in $\mathrm{Kg} \mathrm{ha}^{-1}$ 100-30-150, P1T1: $5 \mathrm{t} \mathrm{ha}^{-1}$ of poultry litter and N-P-K in Kg ha ${ }^{-1} 200-60-300, \mathrm{P} 1 \mathrm{~T} 2: 5 \mathrm{t} \mathrm{ha}^{-1}$ of poultry litter and N-P-K in $\mathrm{Kg} \mathrm{ha}^{-1}$ 400-120-600, Р1T3: $5 \mathrm{t} \mathrm{ha}^{-1}$ of poultry litter and N-P-K in $\mathrm{Kg} \mathrm{ha}^{-1}$ 600-180-900, P2T0: $10 \mathrm{t} \mathrm{ha}^{-1}$ of poultry litter and N-P-K in Kg ha ${ }^{-1} 100-30-150$, P2T1: $10 \mathrm{t} \mathrm{ha}^{-1}$ of poultry litter and N-P-K in $\mathrm{Kg} \mathrm{ha}^{-1}$ 200-60-300, P2T2: $10 \mathrm{t} \mathrm{ha}^{-1}$ of poultry litter and N-P-K in $\mathrm{Kg} \mathrm{ha}^{-1} 400-120-600$, P2T3: $10 \mathrm{t} \mathrm{ha}^{-1}$ of poultry litter and N-P-K in $\mathrm{Kg} \mathrm{ha}^{-1}$ 600-180-900. 

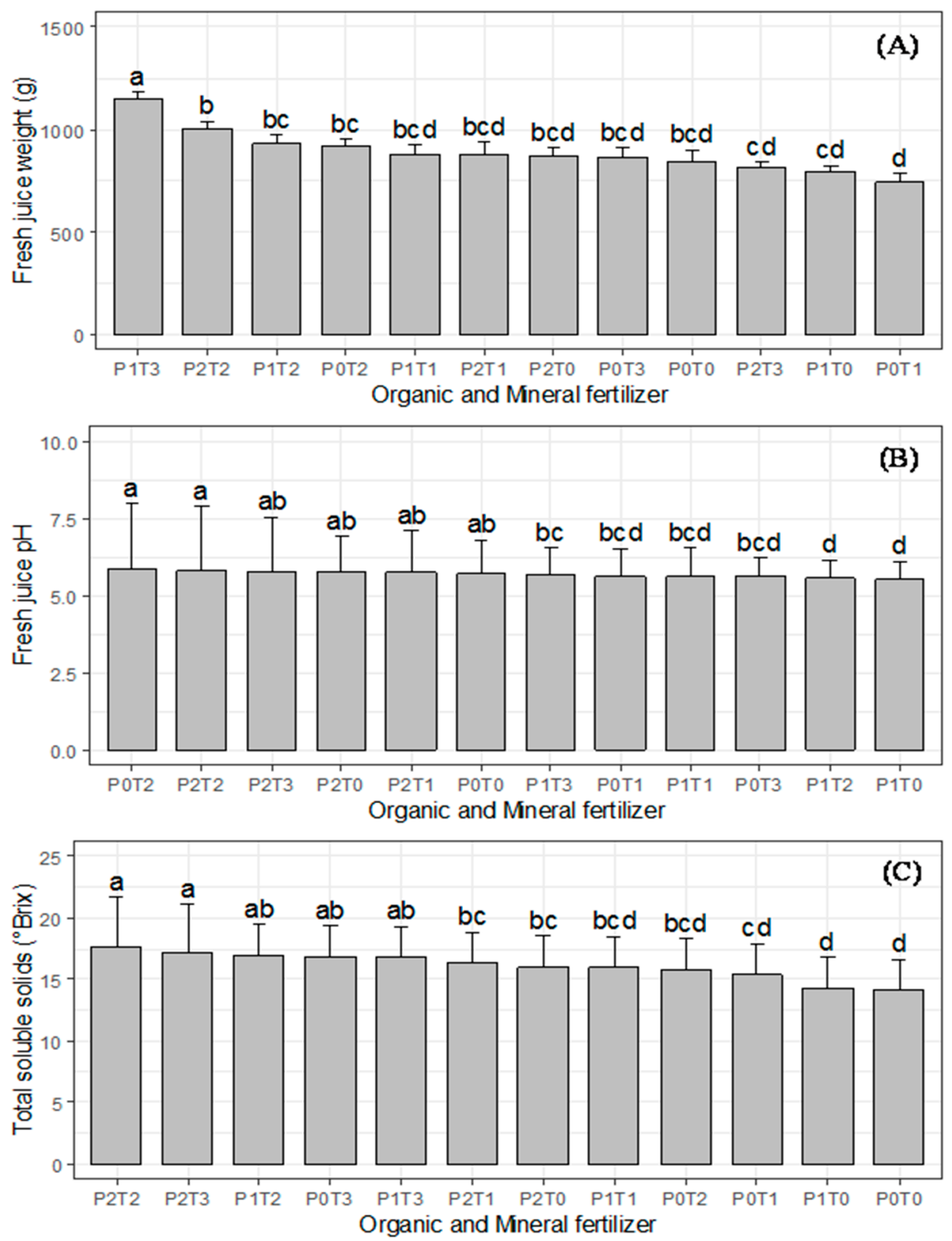

Figure 2. Effect of organo-mineral fertilizer on average fruit quality attributes: (A) fresh juice weight; (B) fresh juice $\mathrm{pH}$; (C) Total soluble solids. P0T0: $0 \mathrm{t} \mathrm{ha}^{-1}$ of poultry litter and N-P-K in $\mathrm{Kg} \mathrm{ha}^{-1}$ 100-30-150, P0T1: $0 \mathrm{t} \mathrm{ha}^{-1}$ of poultry litter and N-P-K in $\mathrm{Kg} \mathrm{ha}^{-1}$ 200-60-300, P0T2: $0 \mathrm{t} \mathrm{ha}^{-1}$ of poultry litter and N-P-K in $\mathrm{Kg} \mathrm{ha}^{-1} 400-120-600$, P0T3: $0 \mathrm{t} \mathrm{ha}^{-1}$ of poultry litter and N-P-K in $\mathrm{Kg} \mathrm{ha}^{-1}$ 600-180-900, P1T0: $5 \mathrm{t} \mathrm{ha}^{-1}$ of poultry litter and N-P-K in $\mathrm{Kg} \mathrm{ha}^{-1}$ 100-30-150, P1T1: $5 \mathrm{t} \mathrm{ha}^{-1}$ of poultry litter and N-P-K in Kg ha ${ }^{-1} 200-60-300, \mathrm{P} 1 \mathrm{~T} 2: 5 \mathrm{t} \mathrm{ha}^{-1}$ of poultry litter and N-P-K in Kg ha ${ }^{-1}$ 400-120-600, P1T3: $5 \mathrm{t} \mathrm{ha}^{-1}$ of poultry litter and N-P-K in $\mathrm{Kg} \mathrm{ha}^{-1}$ 600-180-900, P2T0: $10 \mathrm{t} \mathrm{ha}^{-1}$ of poultry litter and N-P-K in Kg ha ${ }^{-1} 100-30-150$, P2T1: $10 \mathrm{t} \mathrm{ha}^{-1}$ of poultry litter and N-P-K in $\mathrm{Kg} \mathrm{ha}^{-1}$ 200-60-300, P2T2: $10 \mathrm{t} \mathrm{ha}^{-1}$ of poultry litter and N-P-K in $\mathrm{Kg} \mathrm{ha}^{-1} 400-120-600, \mathrm{P} 2 \mathrm{~T} 3: 10 \mathrm{t} \mathrm{ha}^{-1}$ of poultry litter and N-P-K in $\mathrm{Kg}^{-1}$ 600-180-900. 


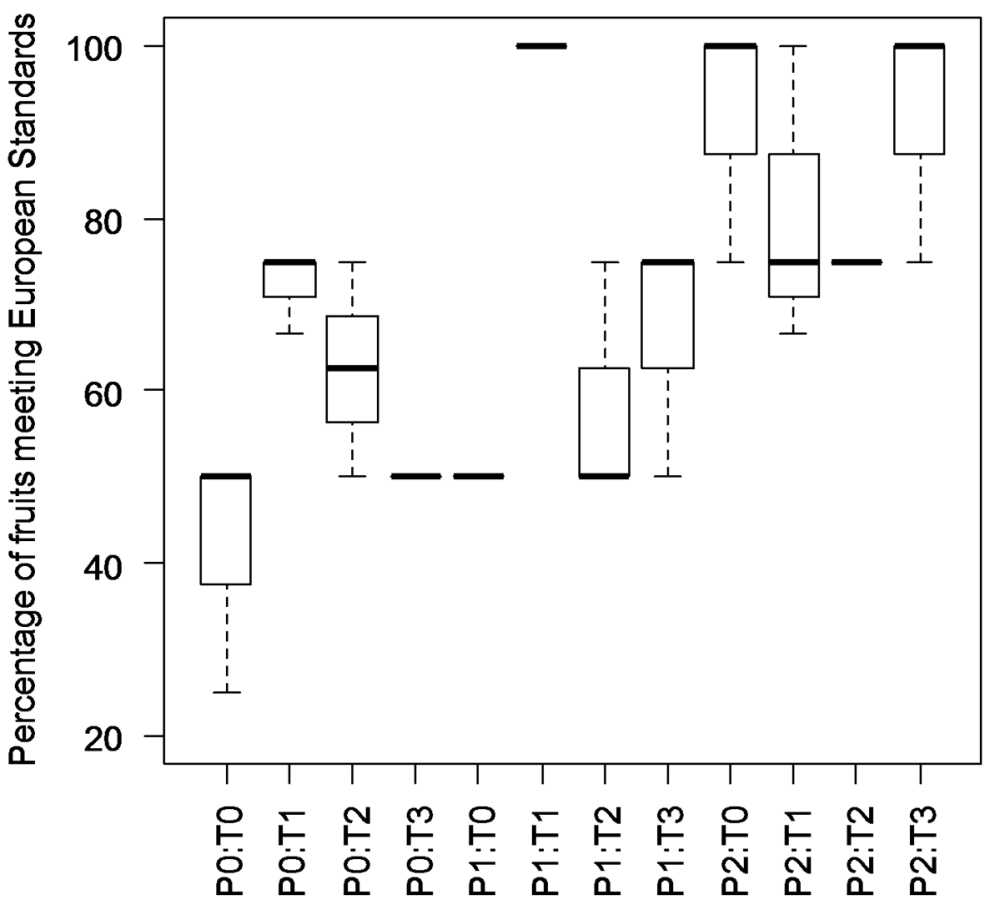

Figure 3. Effect of organo-mineral fertilizer on percentage of fruits meeting European standards. P0T0: $0 \mathrm{t} \mathrm{ha}^{-1}$ of poultry litter and N-P-K in $\mathrm{Kg} \mathrm{ha}^{-1} 100-30-150, \mathrm{P} 0 \mathrm{~T} 1: 0 \mathrm{tha}{ }^{-1}$ of poultry litter and N-P-K in $\mathrm{Kg} \mathrm{ha}^{-1}$ 200-60-300, P0T2: $0 \mathrm{t} \mathrm{ha}^{-1}$ of poultry litter and N-P-K in $\mathrm{Kg} \mathrm{ha}^{-1} 400-120-600$, P0T3: $0 \mathrm{t} \mathrm{ha}^{-1}$ of poultry litter and N-P-K in Kg ha ${ }^{-1} 600-180-900$, P1T0: $5 \mathrm{t} \mathrm{ha}^{-1}$ of poultry litter and N-P-K in $\mathrm{Kg} \mathrm{ha}^{-1}$ 100-30-150, P1T1: $5 \mathrm{t} \mathrm{ha}^{-1}$ of poultry litter and N-P-K in $\mathrm{Kg}^{-1}$ 200-60-300, P1T2: $5 \mathrm{t} \mathrm{ha}^{-1}$ of poultry litter and N-P-K in $\mathrm{Kg} \mathrm{ha}^{-1} 400-120-600$, P1T3: $5 \mathrm{t} \mathrm{ha}^{-1}$ of poultry litter and N-P-K in $\mathrm{Kg} \mathrm{ha}^{-1}$ 600-180-900, Р2T0: $10 \mathrm{tha}^{-1}$ of poultry litter and N-P-K in $\mathrm{Kg} \mathrm{ha}^{-1}$ 100-30-150, P2T1: $10 \mathrm{t} \mathrm{ha}^{-1}$ of poultry litter and N-P-K in Kg ha ${ }^{-1} 200-60-300$, P2T2: $10 \mathrm{t} \mathrm{ha}^{-1}$ of poultry litter and N-P-K in $\mathrm{Kg} \mathrm{ha}^{-1}$ 400-120-600, Р2T3: $10 \mathrm{t} \mathrm{ha}^{-1}$ of poultry litter and N-P-K in $\mathrm{Kg} \mathrm{ha}^{-1} 600-180-900$.

\subsection{Relation between Fruit Quality Attributes for Predicting Fruit Acceptability for European Exportation}

Correlations between fruit weight and size and fruit pulp contents were presented in Table 3. Fruit weight was positively significantly correlated to number of fruitlets, $\mathrm{pH}$ and juice yield $(p<0.001)$, and to infructescence length $(p<0.05)$. It was negatively related to crown length $(p<0.01)$, meaning that crown growth negatively impacts on fruit growth. The ratio crown length: fruit length and the ratio of crown length: core diameter length were negatively correlated to fruit weight, number of fruitlets and juice yield $(p<0.001)$. This implies that the higher these ratios are, the weaker the fruit and juice yield are. Infructescence, crown length and weight were positively correlated and all of them were also positively correlated to the ratio crown length: fruit length and the ratio of crown length: core diameter length $(p<0.001)$. Surprisingly, these latter ratios were not correlated to juice quality attributes ( $\mathrm{pH}$ and total soluble solids). Fruit weight, infructescence length, number of fruitlets, and number of spirals were positively correlated to $\mathrm{pH}$. 
Table 3. Correlation between fruit quality attributes for exportation.

\begin{tabular}{|c|c|c|c|c|c|c|c|c|c|c|c|c|}
\hline & FW & IL & CL & $\mathrm{CW}$ & RCF & RCD & FCD & NF & NS & TSS & $\mathrm{pH}$ & JY \\
\hline FW & 1 & & & & & & & & & & & \\
\hline IL & 0.187 * & 1 & & & & & & & & & & \\
\hline $\mathrm{CL}$ & $-0.260 * *$ & $0.862^{* * *}$ & 1 & & & & & & & & & \\
\hline CW & -0.027 & $0.875^{* * *}$ & $0.869^{* * *}$ & 1 & & & & & & & & \\
\hline RCF & $-0.562 * * *$ & $0.570^{* * *}$ & $0.902 * * *$ & $0.683^{* * *}$ & 1 & & & & & & & \\
\hline $\mathrm{RCD}$ & $-0.456^{* * *}$ & $0.706^{* * *}$ & $0.938^{* * *}$ & $0.761^{* * *}$ & $0.929^{* * *}$ & 1 & & & & & & \\
\hline FCD & 0.074 & -0.011 & -0.056 & -0.033 & -0.069 & $-0.282 * *$ & 1 & & & & & \\
\hline $\mathrm{NF}$ & $0.794^{* * *}$ & 0.108 & $-0.325^{* * *}$ & -0.153 & $-0.612 * * *$ & $-0.502 * * *$ & 0.082 & 1 & & & & \\
\hline NS & 0.02 & 0.06 & 0.077 & 0.081 & 0.077 & 0.058 & 0.022 & 0.074 & 1 & & & \\
\hline $\mathrm{pH}$ & $0.375 * * *$ & $0.166 *$ & 0.005 & 0.058 & -0.104 & -0.116 & 0.117 & $0.359 * * *$ & $0.220 *$ & 0.15 & 1 & \\
\hline JY & $0.888^{* * *}$ & 0.127 & $0.312^{* * *}$ & -0.1 & $-0.595^{* * *}$ & $-0.494^{* * *}$ & 0.056 & $0.799 * * *$ & 0.04 & 0.144 & $0.372^{* * *}$ & 1 \\
\hline
\end{tabular}

diameter, $\mathrm{NF}=$ number of fruitlets, NS = number of spirals, TSS $=$ total soluble solids, $\mathrm{JY}=$ juice crown length: Fruit length, $\mathrm{RCD}=$ ratio crown length: core diameter, $\mathrm{FCD}=$ fruit core $p<0.01 ; * * *$ statistically significant at $p<0.001$. 


\subsection{Influence of Organo-Mineral Fertilization on Pineapple Fresh Fruit Quality Meeting Local Acceptability}

3.4.1. Influence of Organo-Mineral Fertilization on Some Sensory Properties of Fresh Pineapple Fruit

The treatments P0T2 and P2T1 were characterized by sweet fruit (V. test $\geq 2, p<5 \%$ ), whereas P0T0 and P2T0 produced a very weak sweet taste fruit (V. test $\leq-2, p<0.05$ ) (Figure 4A). A higher acidic taste was obtained with P0T0, P0T1, and P2T0, while a lower acidic taste was obtained with P0T2, P1T1, P1T3, P2T1 and P2T2 (Figure 4B). A more aromatized fruit was obtained with P0T2 and P2T1 (Figure 4C). A weakly flavored juice particularized P1T0 and P2T3 (Figure 4C). Higher fibrous fruit were obtained with P1T3, while lower fibrous fruit were obtained with P0T2, P2T1, and P2T3 (Figure 4D).

A Sweetness

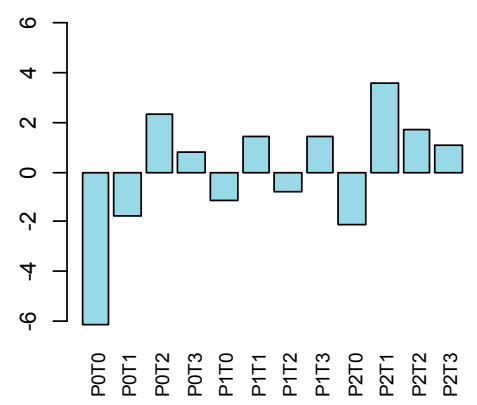

C Aroma

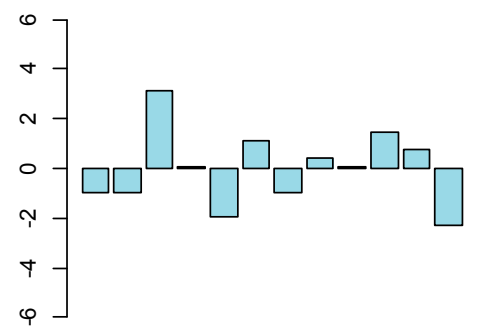

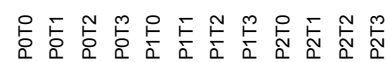

B Acidity

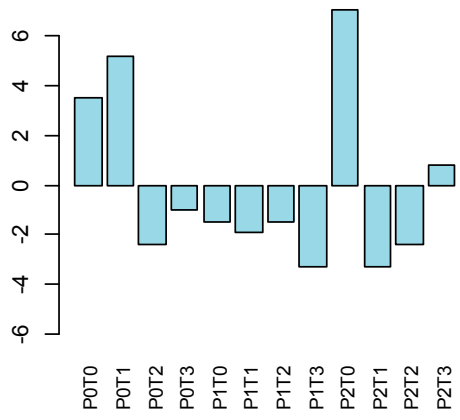

D Fiber

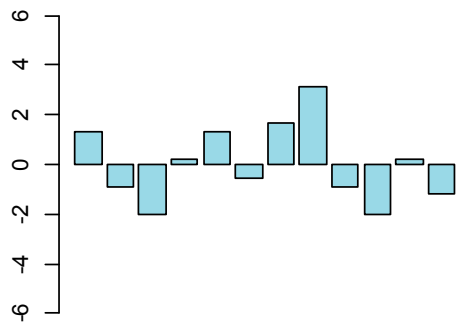

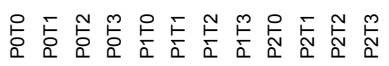

Figure 4. Sensory profile of fruit from organo-mineral fertilizers: (A) sweetness; (B) acidity; (C) Aroma; (D) Fiber. On the Y axis, V-computed from the V-test in comparison of the mean value of the sensorial parameter for a given treatment to the overall mean. A V-computed greater than 2 means the treatment had significantly $(p<0.05)$ greater value for the given parameter. But $t$-computed lower than -2 implies that the treatment had significantly lower $(p<0.05)$ value for the given parameter. P0T0: $0 \mathrm{t} \mathrm{ha}^{-1}$ of poultry litter and N-P-K in $\mathrm{Kg} \mathrm{ha}^{-1} 100-30-150$, P0T1: $0 \mathrm{t} \mathrm{ha}^{-1}$ of poultry litter and N-P-K in $\mathrm{Kg} \mathrm{ha}^{-1}$ 200-60-300, P0T2: $0 \mathrm{t} \mathrm{ha}^{-1}$ of poultry litter and N-P-K in Kg ha ${ }^{-1}$ 400-120-600, P0T3: $0 \mathrm{t} \mathrm{ha}^{-1}$ of poultry litter and N-P-K in Kg ha ${ }^{-1} 600-180-900$, P1T0: $5 \mathrm{t} \mathrm{ha}^{-1}$ of poultry litter and N-P-K in $\mathrm{Kg} \mathrm{ha}^{-1}$ 100-30-150, P1T1: $5 \mathrm{t} \mathrm{ha}^{-1}$ of poultry litter and N-P-K in $\mathrm{Kg} \mathrm{ha}^{-1}$ 200-60-300, P1T2: $5 \mathrm{t} \mathrm{ha}^{-1}$ of poultry litter and N-P-K in Kg ha ${ }^{-1} 400-120-600$, P1T3: $5 \mathrm{t} \mathrm{ha}^{-1}$ of poultry litter and N-P-K in $\mathrm{Kg} \mathrm{ha}^{-1}$ 600-180-900, Р2T0: $10 \mathrm{t} \mathrm{ha}^{-1}$ of poultry litter and N-P-K in $\mathrm{Kg} \mathrm{ha}^{-1}$ 100-30-150, P2T1: $10 \mathrm{t} \mathrm{ha}^{-1}$ of poultry litter and N-P-K in Kg ha ${ }^{-1} 200-60-300$, P2T2: $10 \mathrm{t} \mathrm{ha}^{-1}$ of poultry litter and N-P-K in $\mathrm{Kg} \mathrm{ha}^{-1}$ 400-120-600, P2T3: $10 \mathrm{t} \mathrm{ha}^{-1}$ of poultry litter and N-P-K in $\mathrm{Kg} \mathrm{ha}^{-1} 600-180-900$.

\subsubsection{Sensory Characteristics Determining Overall Acceptability}

The fruit aroma was positively correlated to sweetness $(p<0.01)$. The latter was negatively correlated to acidity $(p<0.001)$. There was no significant correlation between fiber content and other 
sensorial parameters. The acceptability was positively correlated to aroma $(p<0.05)$ and sweetness $(p<0.001)$ and negatively to acidity $(p<0.001)$ and fiber content $(p<0.05)$ (Table 4$)$.

Table 4. Correlation between acceptability and sensorial characteristics.

\begin{tabular}{|c|c|c|c|c|c|}
\hline & Aroma & Sweetness & Acidity & Fiber & Acceptability \\
\hline Aroma & 1 & & & & \\
\hline Sweetness & $0.18^{* *}$ & 1 & & & \\
\hline Acidity & -0.04 & $-0.34^{* * *}$ & 1 & & \\
\hline Fiber & 0.01 & -0.01 & 0.11 & 1 & \\
\hline Acceptability & $0.14^{*}$ & $0.53^{* * *}$ & $-0.34^{* * *}$ & -0.14 * & 1 \\
\hline
\end{tabular}

The preference mapping showed that fruits from P0T2, P2T1, P1T3, and P2T2 were highly appreciated by $70 \%$ of consumers. The treatments P0T3 and P1T1 were moderately appreciated by $60 \%$ and the least preferred were P0T0, P1T0, P2T0, P0T1, and P1T2 (Figure 5). The treatments P0T2, P2T1, P1T3, and P2T2 were then promising for smooth cayenne pineapple production.

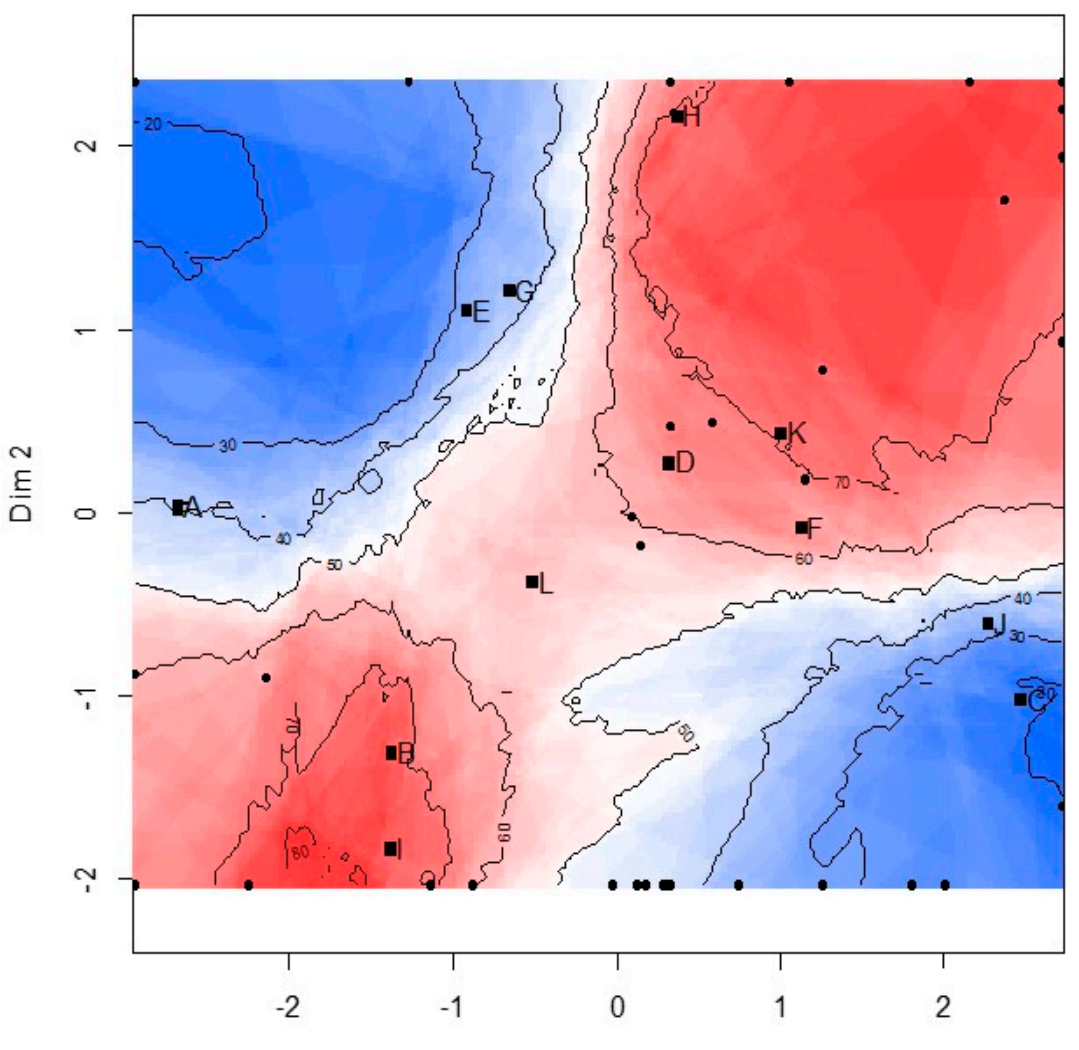

$\operatorname{Dim} 1$

Figure 5. Preference mapping. A = P0T0: $0 \mathrm{t} \mathrm{ha}^{-1}$ of poultry litter and N-P-K in Kg ha ${ }^{-1}$ 100-30-150, B = P2T1: $10 \mathrm{t} \mathrm{ha}^{-1}$ of poultry litter and N-P-K in Kg ha ${ }^{-1}$ 200-60-300, C = P2T0: $10 \mathrm{tha}^{-1}$ of poultry litter and N-P-K in Kg ha ${ }^{-1}$ 100-30-150, D = P0T3: $0 \mathrm{t} \mathrm{ha}^{-1}$ of poultry litter and N-P-K in $\mathrm{Kg}^{-1}$ 600-180-900, E = P1T0: $5 \mathrm{t} \mathrm{ha}^{-1}$ of poultry litter and N-P-K in Kg ha ${ }^{-1} 100-30-150, \mathrm{~F}=\mathrm{P} 1 \mathrm{~T} 1: 5 \mathrm{tha}^{-1}$ of poultry litter and N-P-K in Kg ha ${ }^{-1} 200-60-300, \mathrm{G}=\mathrm{P} 1 \mathrm{~T} 2$ : $5 \mathrm{t} \mathrm{ha}^{-1}$ of poultry litter and N-P-K in $\mathrm{Kg} \mathrm{ha}^{-1} 400-120-600, \mathrm{H}=\mathrm{P} 1 \mathrm{T3}: 5 \mathrm{t} \mathrm{ha}^{-1}$ of poultry litter and N-P-K in Kg ha ${ }^{-1}$ 600-180-900, I = P0T2: $0 \mathrm{t} \mathrm{ha}^{-1}$ of poultry litter and N-P-K in Kg ha ${ }^{-1} 400-120-600, \mathrm{~J}=\mathrm{P} 0 \mathrm{~T} 1: 0 \mathrm{t} \mathrm{ha}^{-1}$ of poultry litter and N-P-K in Kg ha ${ }^{-1}$ 200-60-300, K = P2T2: $10 \mathrm{t} \mathrm{ha}^{-1}$ of poultry litter and N-P-K in Kg ha ${ }^{-1} 400-120-600$, $\mathrm{L}=\mathrm{P} 2 \mathrm{~T} 3: 10 \mathrm{tha}^{-1}$ of poultry litter and N-P-K in $\mathrm{Kg} \mathrm{ha}^{-1} 600-180-900$. 


\section{Discussion}

\subsection{Influence of Organo-Mineral Fertilization on Fruit Yield and Quality Attributes}

Organo-mineral fertilization has positively influenced fruit yield and its physico-chemical characteristics. Research findings on organic or organo-mineral influence on pineapple are little documented. Only the livestock component of the smallholder farms of Uganda with the aim of proposing a better integrated pineapple crop-livestock production was described by [19]. In this work, the addition of organic, i.e., poultry dung to mineral fertilizer enabled a higher fruit weight compared to mineral applied alone. These findings are not consistent with [18] who found that integrated fertilization (Mucuna pruriens green manure associated with $265.5 \mathrm{~kg} \mathrm{ha}^{-1} \mathrm{~N}, 10.53 \mathrm{~kg} \mathrm{ha}^{-1} \mathrm{P}$ and $445.71 \mathrm{~kg} \mathrm{ha}^{-1} \mathrm{~K}$ ) had similar fruit weight and number of fruitlets as those of conventional fertilization, whereas its crown weight was similar to that of organic fertilization on the Queen Victoria pineapple in Reunion Island. In terms of fruit chemical characteristics, even though the interaction between organic manure and mineral fertilization was not significant, the higher rate of poultry dung (P2 = $10 \mathrm{t} \mathrm{ha}^{-1}$ ) had significantly higher total soluble solids and $\mathrm{pH}$. These results were in agreement with those of Darnaudery et al. [18] who found that fruits from organic and integrated fertilization were significantly less acidic.

\subsection{Acceptability for Exportation and Domestic Consumption of Pineapple as Affected by Organo-Mineral Fertilization}

Organo-mineral fertilization has influenced fruit physico-chemical and organoleptic characteristics of pineapple smooth cayenne and, as a result, determines its acceptability for exportation or for local consumption.

The influence of mineral and/or organic fertilizer on fruit weight and quality attributes has been reported by many authors [25,29-32] but information on how fertilization affected the percentage of fruit meeting European standards and domestic preference have not been reported so far. Our results suggested that organo-fertilizer achieving exportation standards may differ from those satisfying domestic preferences. Consequently, optimum rates of organo-fertilizer to advocate to farmers should respect the destination of the production.

Our findings indicated the sensorial characteristics aroma, sweetness, acidity, and fiber determine the acceptability of pineapple for fresh consumption in Benin. These results are in agreement with the findings of Djalalou [4] who found that consumers' quality standards in domestic (Cotonou, Porto-Novo, Calavi, Sème, etc.), border, and regional markets (Krake, Lomé, Grand Popo, Lagos, etc.) are largely taste related. Sensorial quality attributes for fresh pineapple have not been developed so far. However, beyond a product's visual appearance, consumers expect quality in terms of their organoleptic, sanitary, and nutritional aspects [21]. Previous work in Benin focused on physical preference attributes. Consumer-merchants reject damaged pineapples, which are difficult to sell for fresh consumption, and also dislike large pineapples, which are difficult to transport on their heads or motorcycles [33]. The size, shape, color, and characteristics of the pulp and sensory properties are the characteristics that determine the acceptability of the product on the market [34]. The correlation between the ratio crown-infructescence length with the chemical quality attributes (total solid soluble, $\mathrm{pH}$ ) is not surprisingly significant. The optimum range for this ratio for pineapple meeting export standards is 0.5-1.5 [22]. Our findings suggest that the ratio crown length: fruit length is not significantly related to physico-chemical quality. This implies that even pineapples with a too long crown can be of good physico-chemical quality. In this way, [35] propose an additional fruit class for exportation whereby fruit would be neatly decrowned in the packing shed and shipped for sale in supermarkets to consumers; this is a class which does not yet exist. 


\section{Conclusions}

The study revealed that organo-mineral fertilization positively influenced fruit physico-chemical and organoleptic characteristics of pineapple smooth cayenne and, as a result, determined its acceptability for exportation or for local consumption. Higher effects of organo-mineral fertilizer on percentage of fruits meeting export standards were found. Optimum organo-fertilizer achieving fruit quality meeting exportation standards differ from those satisfying domestic preferences. Consequently, organo-fertilizer recommendation to farmers should respect the destination of the production. The findings indicated that the sensorial characteristics aroma, sweetness, acidity, and fiber determine the acceptability of pineapple for fresh consumption in Benin. Moreover, the findings suggested that the ratio crown-infructescence length, which is a key ratio for exportation standards, is not related to physico-chemical quality. So far, no literature has reported the relation between the ratio crown length: fruit length and quality attributes. To conclude, these findings have implications for the sustainability of pineapple production for domestic consumption and exportation purposes.

Author Contributions: E.L.S., C.E.A., and R.T. performed the research design, data collection, data analysis, and wrote the manuscript. G.D., P.G.T., and G.L.A. contributed significantly to manuscript improvement.

Funding: This work was partly supported by DAAD through the "Centre de Recherche pour l'Amélioration à l'Adaptation à la Sécheresse (CERAAS)".

Acknowledgments: We are also grateful to anonymous reviewers for their comments on the earlier draft.

Conflicts of Interest: The authors declare no conflicts of interest.

\section{References}

1. FAOSTAT. Database. 2015. Available online: http://faostat3.fao.org/faostat-gateway/go/to/browse/Q/\$ ast\$/E (accessed on 20 January 2016).

2. Chogou, S.K.; Gandonou, E.; Fiogbe, N. Mesure de l'efficacité technique des petits producteurs d'ananas au Bénin. Cah. Agric. 2017, 26, 25004. [CrossRef]

3. FRuiTROP. Dossier du Mois D'ananas. 2013. Available online: http://passionfruit.cirad.fr (accessed on 21 January 2019).

4. Djalalou-Dine, A.A.A. Governance, Marketing and Innovations in Beninese Pineapple Supply Chains. A Survey of Smallholder Farmers in South Benin. Ph.D. Thesis, Wageningen University, Wageningen, The Netherland, 2013.

5. Moser, R.; Raffaelli, R.; Thilmany-McFadden, D. Consumer preferences for fruit and vegetables with credence-based attributes: A review. Int. Food Agribus. Manag. Rev. 2011, 14, 121-141.

6. Loeillet, D. Le marché mondial de l'ananas. Fruitrop 2013, 215, 32-39.

7. Teixeira, L.A.J.; Quaggio, J.A.; Cantarella, H.; Mellis, E.V. Potassium fertilization for pineapple: Effects on plant growth and fruit yield. Rev. Bras. Frutic. 2011, 33, 618-626. [CrossRef]

8. Dorey, E.P.; Fournier, M.L.; Tixier, P. Validity of the pineapple crop model SIMPIÑA across the climatic in Réunion Island. Eur. J. Agron. 2015, 62, 1-12. [CrossRef]

9. Khamsouk, B.; Roose, E. Runoff and erosion of a tropical volcanic soil (nitisol) cultivated in intensive crop systems in Martinique. Cah. Agric. 2003, 12, 145-151.

10. Echeverria-Saenz, S.F.; Mena, M.; Pinnock, C.; Ruepert, K.; Solano, E.; De la Cruz, B.; Campos, J.; Sanchez-Avila, S.L.; Barata, C. Environmental hazards of pesticides from pineapple crop production in the Rio Jimenez watershed (Caribbean Coast, Costa Rica). Sci. Total Environ. 2012, 440, 106-114. [CrossRef]

11. Animesh, D.; Chaudhuri, P.S. Earthworm community structure of pineapple (Ananas comosus) plantations under monoculture and mixed culture in West Tripura, India. Trop. Ecol. 2014, 55, 1-17.

12. Tossou, C. Impact de la Culture de L'ananas sur L'environnement dans le Département de l'Atlantique (République du Bénin), Mémoire de fin de Cycle Pour L'obtention du Diplôme d'Etudes Supérieures Spécialisées en Aménagement et Gestion des Ressources Naturelles; Faculté des Sciences Agronomiques, Université d'Abomey-Calavi: Abomey-Calavi, Bénin, 2001. 
13. Amusan, A.O.; Adetunji, M.T.; Azeez, J.O.; Bodunde, J.G. Effect of the Integrated Use of Legume Residue, Poultry Manure and Inorganic Fertilizers on Maize Yield, Nutrient Uptake and Soil Properties. Nutr. Cycl. Agroecosyst. 2011, 90, 321-330. [CrossRef]

14. Liu, C.H.; Liu, Y. Influences of organic manure addition on the maturity and quality of pineapple fruits ripened in winter. J. Soil Sci. Plant Nutr. 2012, 12, 211-220. [CrossRef]

15. Amoah, A.A.; Masateru, S.; Shuichi, M. Effects of Soil Fertility Management on Growth, Yield and Water-Use Efficiency of Maize (Zea Mays L.) and Selected Soil Properties'. Soil Sci. Plant Anal. 2012, 43, 924-935. [CrossRef]

16. Kihara, J.; Bationo, A.; Mugendi, D.N.; Martius, C.; Vlek, P.L.G. Conservation Tillage, Local Organic Resources and Nitrogen Fertilizer Combinations Affect Maize Productivity, Soil Structure and Nutrient Balances in Semi-Arid Kenya. Nutr. Cycl. Agroecosyst. 2011, 90, 213-225. [CrossRef]

17. Chivenge, P.; Bernard, V.; Johan, S. Does the Combined Application of Organic and Mineral Nutrient Sources Influence Maize Productivity? A Meta-Analysis. Plant Soil 2011, 342, 1-30. [CrossRef]

18. Darnaudery, M.; Fournier, P.; Lechaudel, M. Low input pineapple crops with high quality fruit: Promising impacts of locally integrated and organic fertilization compared to chemical fertilizer. Exp. Agric. 2016, 1-17. [CrossRef]

19. Nalubwama, S.; Vaarst, M.; Kabi, F.; Kiggundu, M.; Bagamba, F.; Odhong, C.; Mugisha, A.; Halberg, N. Challenges and Prospects of Integrating Livestock into Smallholder Organic Pineapple Production in Uganda. Livestock Research for Rural Development 2014. Available online: http:/ /www.lrrd.org/lrrd26/6/cont2606. htm (accessed on 1 October 2018).

20. Caetano, L.; Ventura, J.; Costa, A.; Guarçoni, R. Efeito da adubação com nitrogênio, fósforo e potássio no desenvolvimento, na produção e na qualidade de frutos do abacaxi ‘Vitória'. Rev. Bras. Frutic. 2013, 35, 883-890. [CrossRef]

21. Codex Alimentarius. Codex Standard for Pineapples 2005. Available online: http:/ /www.codexalimentarius. net/web/standard_list.do\# (accessed on 20 October 2018).

22. Fassinou, H.V.N.; Lommen, W.J.M.; Agbossou, K.E.; Struik, P.C. Influence of weight and type of planting material on fruit quality and its heterogeneity in pineapple [Ananas comosus (L.) Merrill]. Front. Plant Sci. 2015, 5, 798. [CrossRef]

23. Watts, B.M.; Ylimaki, G.L.; Jeffery, L.E.; Elias, L.G. Méthodes de Base pour l'Evaluation Sensorielle des Aliments; CRDI: Ottawa, ON, Canada, 1991; p. 159.

24. Agbangba, C.E.; Dagbenonbakin, G.D.; Djogbénou, C.P.; Houssou, P.; Assea, D.E.; Sossa, E.L.; Kotomalè, U.A.; Ahotonou, P.; Ndiaga, C.; Akpo, L.E. Influence de la fertilisation minérale sur la qualité physico-chimique et organoleptique du jus d'ananas Cayenne lisse au Bénin. Int. J. Biol. Chem. Sci. 2015, 9, 1277-1288. [CrossRef]

25. R Core Team. A Language and Environment for Statistical Computing; R Foundation for Statistical Computing: Vienna, Austria, 2018; Available online: https:/ / www.R-project.org/ (accessed on 15 August 2018).

26. Gomez, K.A.; Gomez, A.A. Statistical Procedures for Agricultural Research, 2nd ed.; John Wiley and Sons: New York, NY, USA, 1984; p. 300.

27. Kuznetsova, A.; Brockhoff, P.B.; Christensen, R.H.B. lmerTest Package: Tests in Linear Mixed Effects Models. J. Stat. Soft. 2017, 82, 1-26. [CrossRef]

28. Husson, F.; Lê, S.; Pagês, G. Exploratory Multivariate Analysis by Exemple, Using R, 1st ed.; CRC Press, Taylor and Françis Group: Abingdon, UK, 2010; p. 205.

29. Teisson, C.; Lacoeuilhe, J.J.; Combres, J.C. Le brunissement interne de l'ananas. Recherches des moyens de lutte. Fruits 1979, 34, 399-415.

30. Reinhardt, D.H.R.C.; Neiva, L.P.A. NPK et sources de potassium dans l'ananas 'Perola' dans la micro-région à Bahia de Feira de Santana. In Congrès International de Fruits; Actes Brésil: Brasília, Brazil, 1986.

31. Paula, M.B.; Carvalho, V.D.; Nogueira, F.D.; Souza, L.F. Efeito da calagem, potássio e nitrogênio na produção e qualidade do fruto do abacaxizeiro. Pesqui Agropecu Bras. 1991, 26, 1337-1343.

32. Spironello, A.; Quaggio, J.A.; Teixeira, L.A.J.; Furlani, P.R.; Sigrist, J.M.M. Pineapple Yield and Fruit Quality Affected by NPK Fertilization in a Tropical Soil. Rev. Bras. Frutic. 2004, 26, 155-159. [CrossRef]

33. Hounhouigan, H.M. Quality of Pasteurised Pineapple Juice in the Context of the Beninese Marketing System. Ph.D. Thesis, University of Wageningen, Wageningen, The Netherland, 2014. 
34. Saradhuldhat, P.; Paull, R.E. Pineapple organic acid metabolism and accumulation during fruit development. Sci. Hortic Amsterdam. 2007, 112, 297-303. [CrossRef]

35. Pineapple news. Newsletter of the Pineapple Working Group; ISHS: Leuven, Belgium, 2013; Volume 20, pp. 1-73. 